\title{
Comparison of Teacher Recruitment and Retention Practices in Cameroonian and Chinese Secondary School: China's Lesson
}

Mathias Guiaké

Phd, Zhejiang Normal University, China, guiakemathias@yahoo.com

Xiaohong Tian

Phd, Zhejiang Normal University, China, tianxiaohong@zjnu.cn

\begin{abstract}
The shortage of teachers in secondary education sector in Cameroon is worrisome. This article examines the practices of teacher recruitment and retention in public secondary school in Cameroon and China by looking at managerial practices. The comparison aimed at finding out what Cameroon could learn from China. The literature review shows very limited comparative studies on teacher recruitment and retention practices. Most studies focused on single countries and particular issues or groups of teachers/schools. This study, however, involves two case studies, especially with China as a country of strong reforms habit. The study employs qualitative approach in which both document analysis and semi-structured in-depth interviews were examined. Documents, including policies, administrative files and trusted reports, depict a macro picture of teacher recruitment and retention in both countries. The interviews data, analysed thematically, aimed to support information from documents. There were 58 respondents participated in the study. The study found out many differences between the two systems. It argued that practices, such as decentralising teacher recruitment, establishing special/affirmative policies for teacher recruitment in underdeveloped areas, improving teachers' living conditions, cooperation between educational stakeholders in developed and disadvantaged areas, and urbanising rural areas' schools are all good experiences Cameroon might learn from China.
\end{abstract}

Keywords: comparative study, teacher recruitment and retention, Cameroon, China

\section{INTRODUCTION}

Cameroon and China are both considered as developing countries but with enormous differences. China is one of the foremost world's economic powers. Its education system is the largest and one of the most diversified education systems in the world (OECD, 2016). It has been for long based on Confucius' philosophy whereas that of Cameroon, due to the European colonisation legacy, is shaped on the French and British systems. Both Cameroon and China hope and consider education as a pillar of development. Education has long been highly valued in China, both by the state, which counts on education's contribution for maintaining China's economic rise, and the parents, who, affected by the One Child Policy, devoted a large proportion of their incomes to their one child's education (Huang et al., 2016). Many theories and scholars have proved the role that education plays in the lives of individuals and societies. One critical actor of this education is the teacher, the one who inculcates or facilitates the transmission of knowledge and skills to the younger generation. However, in many countries, secondary education faces a serious problem of teacher shortages. Unfortunately, Cameroon is one of those countries. Many scholars think the key personnel in school, the actor of transformation and change are teachers. Having a strong supply of high-quality teachers is critically relevant in any education system (Burns \& Darling-Hammond, 2014). Policymakers in different countries attach great

Citation: Guiaké, M., \& Tian, X. (2021). Comparison of teacher recruitment and retention practices in Cameroonian and Chinese secondary school: China's lesson. Anatolian Journal of Education, 6(2), 75-88. https://doi.org/10.29333/aje.2021.627a 
importance to the teacher's issues because teachers are considered as nation-builders (Yang, 2015). Spending on teachers is a productive investment. Hence, efforts should be provided to establish good policies regarding teachers. Studies show that efforts made on education in general and on teachers in particular favour more primary and higher education sectors than the secondary sector. "Governments invest heavily in improving access to quality of primary education, and in developing strong networks of university colleges; the secondary level, while not forgotten, has been given lower priority and has received less attention" (Moraa et al., 2017). International organisations' assistance has largely neglected secondary education in favour of investing in primary education (UNESCO, 1999; Moraa et al., 2017).

The above argument explains the situation of secondary education in Cameroon with a mismanagement affecting the sector due to the lack of attention. Teachers' recruitment, distribution, motivation, retention and professional development remain a big challenge World Bank (2017). The mismanagement has led to a dearth of teachers across the country, and especially in rural areas. Trank et al. (2002) provided evidence that schools are more effective overall when they have developed successful recruitment and retention (R\&R) system. Initiatives and reforms have been introduced in many countries to attract and recruit school teachers, many of which do not have a clear evidence base, so their effectiveness remains unclear (See et al., 2020). To develop a good system of teacher R\&R in Cameroon, we conducted a comparative study in order to learn from others, namely China. A comparative study according to George Bereday is a study that enables us to understand what is going on elsewhere, it allows learning best practices from others and to correct or avoid mistakes in our own system (Gonondo, 2017).

The choice of China in this comparative study is firstly motivated by the fact that China with its large population and the so-called "centralised government" which logically requires an extra effort to meet the needs of each locality, does not record a high rate of teacher shortages like in Cameroon. Secondly, similar to Cameroon, China is a country with a big geographical and regional disparities; some regions are very developed, some are quite developing, and others are underdeveloped (Cochrane \& Rogers, 2019; Haifeng \& Dennis, 2015; Li \& Wei, 2010; Zhang \& Bao, 2015). In respect to the disparities, it has established a series of policies and strategies with special treatment for recruiting teachers in the underdeveloped areas in order to attract and balance the distribution of teachers across the territorywide. Besides, China is enormously investing in urbanising rural areas in order to reduce disparities between regions. These practices of not only issuing special policies to attract teachers in remote areas but also investing heavily in urbanising rural areas could serve as policy perspectives for Cameroon. As a developing country, Chinese experience for investing in human capital, infrastructures and permanent policy reforms, that contributes to China's rise as a second economic power in the world, pushes many developing countries to learn from China. China is doing pretty well in educational policy reforms, with a strong commitment to its implementation and improvement. All these aspects are good experiences Cameroonian educational leaders may learn to overcome the ineffectiveness of teacher managerial practices. With various educational policies aiming at accessing and improving the quality of education, the Chinese government makes great efforts to develop its education sectors. Studies show that in 1949, about 80 per cent of the Chinese population was illiterate, and the students' enrolment rate very low. Today, the percentage of the illiterate population to total aged 15 and over is only 5.28 per cent (China Yearbook, 2017). China counts 5,085 junior secondary schools with about 308, 046 full-time teachers (MoE, 2016), and 13,743 senior secondary schools with 1,698,758 fulltime teachers (Yearbook, 2016). There are about 260 million students and over 15 million teachers in around 514,000 schools in China (Yearbook, 2014). Such efforts are made not only quantitatively but also qualitatively. Huang et al. (2016) witnessed that Chinese educational reforms have long promoted performance outcomes and quality improvements in order to build a prosperous, sustainable and 
harmonious society. All these efforts motivated us to compare the two systems and learn good practices.

This study is in line with the World Bank's endeavour of helping countries share good practices. It is also consistent with UNESCO's objectives for Sustainable Development Goal four and its targets to be reached by 2030. Objectives such as universal primary and secondary education, equal access to education, relevant skills for decent work, universal youth literacy, education for sustainable development and global citizenship, among others, are all linked to some extent to teachers and educators as means to reach those objectives. This is because equal access and quality education for all could not be easily attained if some needs regarding teachers are not met. Hence, addressing teacher's issues are fundamental at this moment in order to meet the 2030 UNESCO's Sustainable Development Goal, especially in those countries where challenges in teacher are still very numerous.

\section{Teacher R\&R: An Overview of the Literature}

\section{Concepts of R\&R as Human Resource Management}

Both recruitment and retention are relevant activities in human resource management of any organisation. According to Wanda (2012), recruitment and selection comprise one of the essential functions of human resources management. They appear most of the time when one identifies a need or vacant post in an organisation. The main aim is to find skilled individuals capable of meeting the objectives of an organisation or institution and retain them. In human resource management, recruitment, selection, and retention constitute the stage that comes after planning. Human resource planning is the first and critical step for any good recruitment and selection. It "involves identifying staffing needs, forecasting available personnel, and determining what additions or replacements are required to maintain a staff of the desired quantity and quality to achieve the organisation's mission" (Lunenburg \& Ornstein, 2012). The overall objective of recruitment and retention, according to Burchill and Casey (1996) is to secure a suitably qualified pool of applicants to fit the organisation's requirements. The concepts of recruitment and retention are two terms that are very crucial in human resource management of any institution or organisation. A well-planned recruitment process, with the right choice, has a positive effect on the labour turnover rate and increase productivity. As the new public management stands for, public institutions should adopt good managerial strategies to meet, with efficacy, their goals.

\section{Policies of Teacher R\&R Practices around the World}

Teacher policies are one of the factors that directly influence the delivery of primary and secondary education (World Bank, 2010). Teacher policies in general and those of recruitment and retention, in particular, are different from one country to another. Generally, teacher policies seek to attract, develop, compensate, and retain effective teachers to improve the quality of education. They are crucial in determining success or failure in education development. Regarding teacher recruitment and retention policies across countries, the OECD Education Committee conducted a study in 2005 aiming at helping countries share innovative and successful initiatives and to identify policy options for attracting, developing and retaining effective teachers. Data collected from 25 countries revealed that virtually all countries use the eligibility criteria involving certification/qualification, citizenship, proficiency in the language of instruction, medical and security checks (OECD, 2005). In addition, some countries require other criteria such as age restrictions, skills tests in literacy, numeracy, and ICT. Existing literature identifies chief recruitment practices such as open recruitment, candidate list, competitive examination, and the combination of two or three of them. "Open recruitment" as the widely used practice, refers to the method in which requested applications for vacancies and selection are decentralised. It is generally under the responsibility of the school or with the coordination of the local authority. "Candidate list" is when the candidates send their name and qualification to the central 
or local authority for the analysis and selection. Concerning competitive examination, it is a centralised exam-based system that allows the selection of candidates for teaching service. The criteria for selection are mostly related to the subject speciality, academic performance or qualification, teaching experiences and skills, results from the competitive examination, interpersonal and skills assessed in interviews, teaching and pedagogical skills.

When it comes to the administration aspect, the review of teacher recruitment and retention in most countries around the world shows that recruitment is under the responsibility of the government (central, regional or local). School involvement in recruitment, selection and retention is less represented. According to the 2005 OECD report, it is only applied in a few countries namely Belgium (Flemish community), Denmark, England and Wales, Hungary, Ireland, Netherland, the Slovak Republic, and Sweden. Despite the fact that most of the countries have a centralised or semicentralised teacher recruitment system, evidence shows that the more schools are involved in teacher's recruitment, and retention, the more their needs are met. In the same vein, a report made by Hamburg cited in (OECD, 2005) noted that "assignment of personnel from a central office meets less and less the needs of the school as well as the applicants of teaching posts. It falls short of the goal of matching the schools' requirements and candidates' qualifications with a view to the particular profile of schools".

The literature review shows very limited comparative studies on teacher $\mathrm{R} \& \mathrm{R}$ practices with regard to learning from each other. Most studies focused on single countries, and according to See et al. (2020), they mostly involve particular issues or groups of teachers/schools. This study, however, not only involves two cases, but its results may apply to any country that experiences the same situation of challenges in teachers. Countries may face different challenges, but teacher issues according to OECD, (2005) and Burns, D., \& Darling-hammond, L. (2014) are high in policy agendas, this is because factors relating to teachers and teaching are the most important influences on student learning. And, teacher recruitment, selection and retention are ones of the most determining process in improving student learning and by extension for the building of knowledge society.

In short, our review mainly focused on the systems and practices from others that may contribute to the improvement of teacher recruitment and retention strategies.

\section{Related Literature in Cameroon and China}

In Cameroon, the majority of schools are facing teacher shortages (Bahtilla, 2017). The World Bank (2010) made a similar observation and stated that there is an acute teacher shortage in Cameroon, especially in the regions not desired by teachers but paradoxically where the need is the greatest. The report showed that if we only consider teachers hired by the government, the PTR (Pupil Teacher Ratios) in some regions like Far-North reached $104 / 1$. The increase of students' number, added to the rate of attrition, retirement, and the use of teachers by other ministries or public institutions have forced the student-parent association to hire more community teachers, which represented 29 per cent of the teaching force in 2013-2014 (World Bank, 2016). Despite continuous external support in the field of teacher recruitment, major structural issues remain unchanged (World Bank, 2016).

Such a situation of teacher's shortage raises the question about the system of recruitment, distribution and retention across the country. To the question, a ministerial circular $\mathrm{N}^{\circ} 004 / \mathrm{CAB} / \mathrm{PM}$ of February 2000 from the Prime Ministry Service related to the admission into national training schools, including recruitment into public service in general, civil servant teachers are recruited and distributed across schools all over the country by the central government (CAB/PM, 2000). In Cameroon, public secondary school teachers are, first of all, recruited into High Teacher Training College (HTTC) through a national competitive examination so as to undergo teaching training. After the completion of the training, they are distributed to the schools by the central government. Yet, according to the World 
Bank (2012), this model of teacher's distribution in Cameroon does not benefit schools with the most significant needs. The distribution of resources remains largely high in wealthier regions and major cities, while rural areas and education priority zones (ZEPs) are underestimated (World Bank, 2018). The observation shows that policymakers and government are not making enough efforts to resolve the issue of teacher shortages in rural areas, for instance. Apart of the failed ZEPs initiative which aimed at determining some poor regions, borderland localities, conflict-affected communities, and refugee localities in order to solve education challenges (Djontu Mouafo, 2013), there is no significant policy with special and practical goals to reduce the gap between disadvantaged and urban areas.

In China, by contrast, plenty of reforms a series of policies have been established to address the issues of teacher shortages and teacher recruitment in disadvantaged areas (Liu, 2011). The Chinese government has made a lot of efforts to resolve the dearth of teacher and their retention; they have not only issued and implemented policies but also heavily invested in local rural economies and societies (Yang, 2015). According to Yiu and Adams (2013), the Chinese government has committed over the last decade to improve teaching quality in rural regions to close the education gap between rural and urban. For this end, many policies deal with strategies on how to recruit more qualified teachers to teach in rural schools. The central government has produced some short-term and temporary policies and programs to address the challenges. For example, college graduates and urban school teachers are encouraged to volunteer-teach in disadvantage areas, and promoting positions are assigned to teach in poor rural schools (MOE 2004; 2006; 2007). Several training campaigns, specifically for rural school teachers, were also organised nationwide.

In addition to the above initiatives, another policy addresses the urbanisation of those rural areas to solve the ruralness challenge (Liu, 2011). This latter aims to urbanise rural areas. It is a reform of the former version which consisted of migrating rural schools to the cities. The former system is judged less relevant for the socio-economic development of the country. Since the launch of the new reform policy aiming to reach about nine hundred million people by 2025 , today, many villages have become small cities (Hillman \& Unger, 2013).

\section{METHOD}

Based on the objectives stated above, the qualitative method has been judged suitable to meet the purpose of this study. The study used qualitative approach because the focus is more on understanding the meaning, the quality of the system/practice than quantification. It is about an in-depth understanding of teacher recruitment and retention such as actors involved, process, and criteria. For this reason, researchers, after analysing document content (official documents such as the national and institutional legislative documents and administrative files which were collected, for most of them, from the ministries of education agencies and institution's websites), have conducted interviews in some areas in Cameroon as well as in China. The interviews data aimed at supporting information from document analysis. Interviews data allowed the researchers to come out with rich and detailed information about teacher recruitment and retention practices in both countries. Both document content and interviews' data were collected from the end of 2017 and the year 2018. The public secondary schools' administrators (school principals and recruitment officers) and teachers have been interviewed in both countries. However, as said, there are about 57,900 junior schools (China Yearbook, 2014) and 13,743 senior secondary schools in China (Yearbook, 2016), and around 3,590 secondary schools throughout Cameroon (Knoema, 2015). With this big picture of secondary schools, it is pretty challenging to include all of the teachers and school administrators from all areas. The target population regarding the interviews includes the Far-north and Centre regions in Cameroon and Zhejiang province in China. To get an accurate representation from those areas, participants from both urban and rural localities have been included in each country. These population samples are likely to represent Cameroon and China. In Cameroon, for instance, the teacher recruitment system is a 
nationwide competitive examination in which the central government recruits, selects and distributes teachers all over the country. School only recruits short-time job teachers when there is a shortage. The choice of Far-north and Centre regions is a strategic choice. It is based on the relevance of the information the researchers wanted to collect. The Far-north is considered as the poorest region and the centre as one of the most developed regions. Hence, data from these regions are likely to be representative of the whole country, especially with a common system of teacher recruitment used all over the country.

As for China, although the research focuses on Zhejiang province, the recruitment system is pretty the same throughout the country. It is a 'semi-open system' in which local governments and schools both in collaboration are involved in the recruitment and selection process. Most of the policies regarding the recruitment of teachers or graduates in rural areas are issued nationwide by the central government. That means there is no significant difference between regions when it comes to who recruit and how it happens.

A purposive sampling technique was used to sort respondents. According to Msuya (2017), a "purposive sampling technique allows the researcher to use personal judgment in selecting respondents who suit the needs of the study". This sampling model was then used in order to include any participants judged relevant to provide information the researchers needed. It was based, among others, on the service location, administrative position or type of teacher, and "information rich respondents".

The study's population concerns secondary schools' stakeholders. A total number of fifty-eight respondents participated in this study: 8 recruitment and officers working in the institutions/agencies in charge of teacher recruitment and retention, 4 from each country; 16 school's administrators, 8 in each case; 32 teachers; 16 in each country. The participants are both from rural and urban areas.

Both face-to-face and phone call semi-structured and in-depth interviews have been used. The semistructured interviews were used with all types of respondents (recruitment officers, school's administrators and teachers in both countries). However, to ensure the validity and reliability of the interviews, three groups of interview questions, namely questions for recruitment officers, school's administrators and teachers were designed. The questions' categorisation aimed to be consistent with the competencies of each respondents' group regarding the information needed. Interview questions are the same for respondents from Cameroon and China. Questions covered among many others, inquiry about the authority in charge of teacher recruitment, the state of teachers' shortage, the procedures, main criteria and factors taken into account when recruiting, challenges, retention strategies, and their opinion and suggestions for a better practice). The face-to-face interviews was used to collect data from Chinese informants. They were also used for some Cameroonian informants precisely teachers who are in China during the investigation period. The phone call interviews were used for the remaining of Cameroonian informants who are in Cameroon. The calls were mainly made through WhatsApp. Most participants were contacted in advance to request their participation in the interview. Then, the arrangement regarding the time of the interview was discussed. Special attention was paid to the ethical considerations when conducting the interviews, treating information and its report. For instance, the participants have been guaranteed that personal information and their institutions/schools will be kept anonymous and confidential. Cultural values and traditions were respectfully considered. Informed consent has been provided to the interviewees before starting an interview. They were told to feel free to participate or not and, to withdraw at any time without any worry.

Findings were analysed using thematic content analysis method. In other words, the results were breaking down into main themes in line with analysis 


\section{FINDINGS AND DISCUSSION}

To meet the main research objective on what Cameroon can learn from China, findings from both document analysis and interviews were broken down into thematic content analysis method. The themes include a) authority in charge of teacher recruitment in public secondary school, b) procedures of teacher recruitment and selection, and c) teachers' shortage and causes. In each part, similarities and difference are established so as to identify the best practices and strategies that, especially Cameroon, may learn from China.

\section{Authority in Charge of Teacher Recruitment in Public Secondary School}

The document contents' analysis and interviews' data from both Cameroon and China revealed that in Cameroon, the central government is in charge of teacher recruitment in public secondary schools while in China, it is the responsibility of the local governments or schools.

In Cameroon, the circular $\mathrm{N}^{\circ} 004 / \mathrm{CAB} / \mathrm{PM}$ of February 2000 and annual ministerial orders launching the recruitment of teachers into higher teacher training college (HTTC) clearly stipulate that the central government through the ministries in charge of recruiting candidates into HTTC are the ones that recruit and select teachers (CAB/PM, 2000 \& MINESUP, 2014; 2016; 2017). Three ministries, namely the Ministry of Secondary Education, the Ministry of Higher Education and the Ministry of Public Service and Administrative Reforms, are involved in teacher recruitment practices. The Ministry of Secondary Education (MINESEC) whose teachers are trained makes a census of needs and submits to the Ministry of Higher Education (MINESUP). In turn, the MINESUP launches a competitive examination and trains the future secondary schools' teachers. The Ministry of Public service and Administrative Reforms (MINFOPRA) deals with the registration and follow-up of teachers' careers. The involvement of many ministries in teacher recruitment has led to the confusion from many respondents to determine which ministry is in charge of launching the competitive examination for recruiting candidates into HTTC. During the interviews, many gave different answers. Some of them said the MINESEC; others said the MINFOPRA or the MINESUP.

The MINESUP, in collaboration with the MINESEC, determines the number of candidates to recruit into each major and each institution, the calendar of the entrance examination, the documents to provide, the date of examination, and all the criteria and conditions. To the best of our knowledge, everything regarding teacher recruitment and distribution is done at the level of central government. Respondents reported how this practice of governance leads to the lack of teachers across the country. Many of them highlighted the malpractices of the central government, such as an inappropriate distribution of teachers across the country, a lack of follow-up, a decrease in the number of recruitment rate.

Knowing this mismanagement, and contrary to the school principals' point of view in favour of decentralising the recruitment system, teachers are quite disagreed. Most of them prefer the fact that the government is responsible for recruiting and distributing. According to those teachers, the decentralisation of recruitment and selection practices can lead to a high rate of corruption from the school principals and to the scourges such as favouritism and nepotism. To them, the recruitment and selection will not be any more based on meritocracy if schools were to be in charge, and as result, the quality of education will be compromised.

However, unlike from Cameroon, where there is a centralised system of teacher recruitment and selection, China presents a "semi decentralised" system. Teachers Law of the People's Republic of China, which constitutes one of the official documents reviewed in this study, stipulates that the administrative departments of education at the local level under the State Council shall be in charge of teachers' issues across the country (MoE (Ministry of Education), 1993). Findings from interviews 
have confirmed and deepened the understanding of the Chinese teacher recruitment and distribution system. Depending on a certain ability of schools, it was reported that local governments or schools can be involved in teacher recruitment. In Zhejiang province, for instance, some schools are independent in terms of recruiting teachers. Based on the local ranking, those schools are generally the best schools and are directly under the provincial government. The latter allows them to recruit themselves, teachers, they need. On the other hand, there are schools where teachers are recruited by the local governments (county education boards). This group of schools does not have permission to recruit teachers themselves, except part-time teachers.

In short, compared to the Cameroonian system where teacher recruitment and selection are centralised, the Chinese system is decentralised. The recruitment's responsibility has been given to the provinces, cities, local educational departments, or even schools.

\section{Procedures of Teacher Recruitment and Selection}

After knowing what system of teacher recruitment exists in Cameroon and China, this part presents in details different steps of entering into the teaching profession. Both in Cameroon and China, teacher recruitment follows a competitive examination system. Figures 1, 2 and 3 respectively present the recruitment and selection procedures in public secondary schools in Cameroon, recruitment and selection process in public secondary schools under the local government in China (Zhejiang province), and recruitment procedures in "independent" public secondary schools (schools that are not under the local government or any education board in terms of teacher recruitment and selection) in China (Zhejiang province).

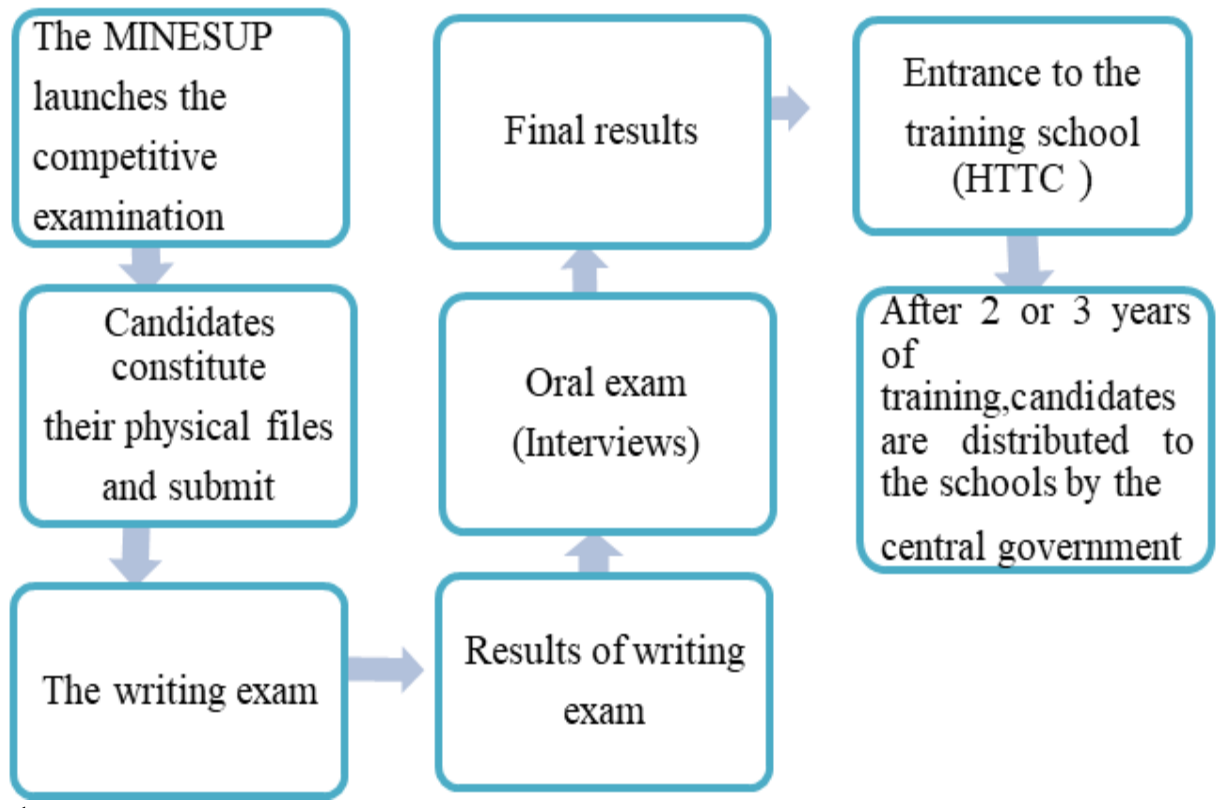

Figure 1

Teacher R\&S procedure in public secondary schools in Cameroon 


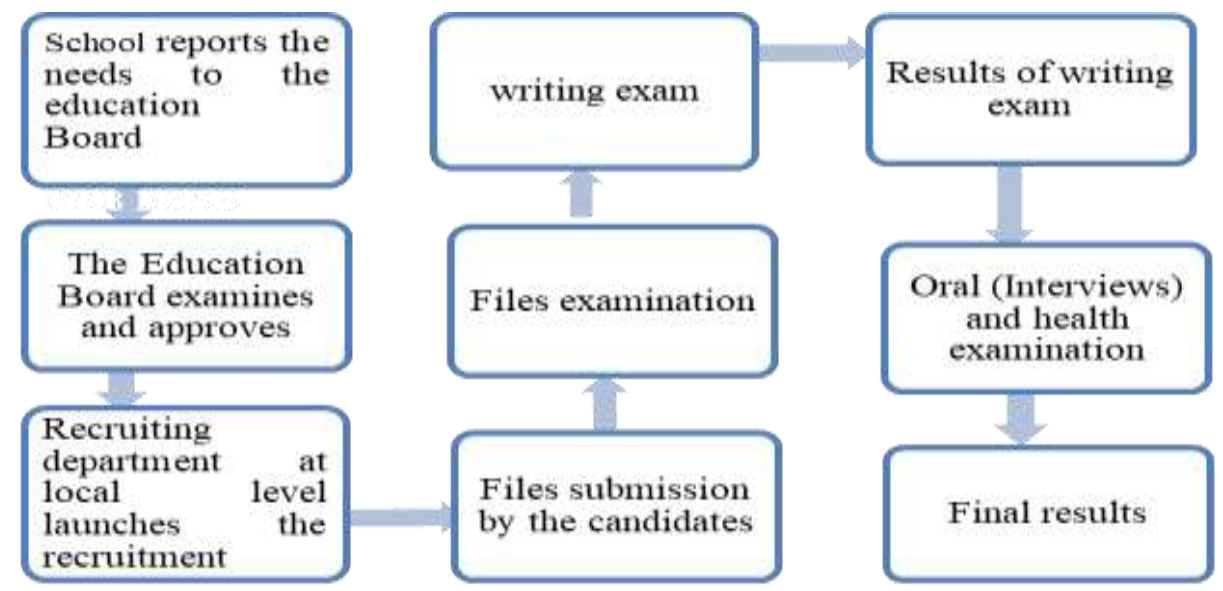

Figure 2

Teacher R\&S process secondary schools under the local government in China (Zhejiang province)

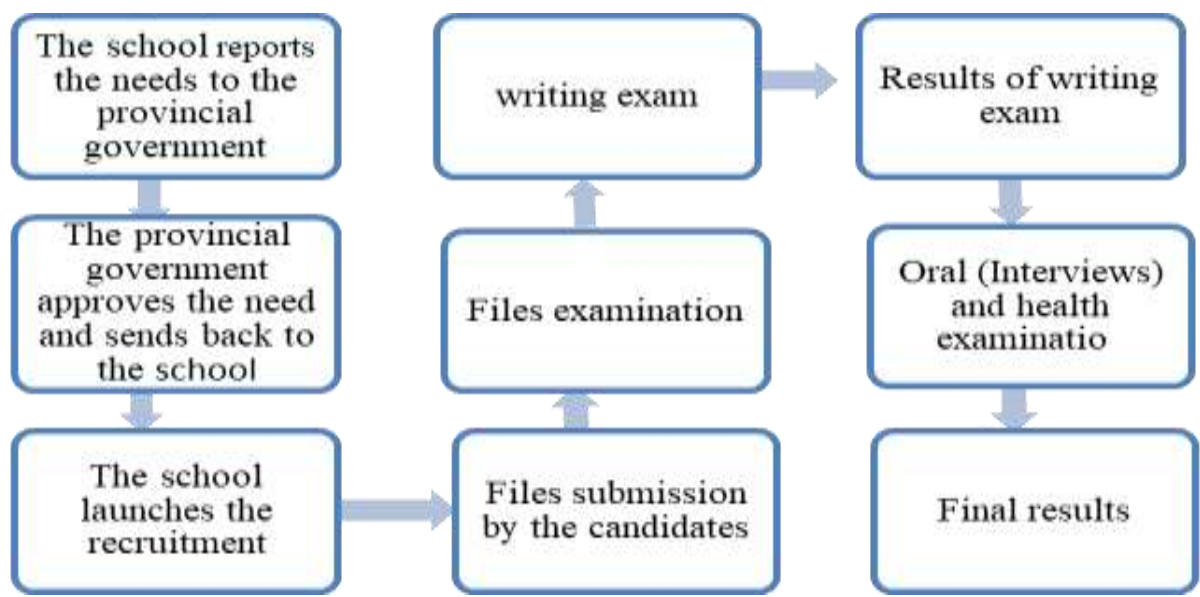

Figure 3

Teacher R\&S procedure in public secondary “independent” schools in China (Zhejiang province)

In Cameroon, once successfully passing the exam, candidates enter to the public high teacher training colleges and spend three years (for those who apply for with General Certificate of Education "Advanced Level"' or Baccalaureate) or two years (for those who enter with Bachelor). Candidates apply for a major related to their background field. Here, the major difference between Cameroon and China is that in Cameroon candidates for teaching profession are trained in HTTC after passing the national competitive examination while in China the training undergoes in the normal universities, normal colleges, normal secondary schools or normal junior colleges before the national examination for teacher qualification. Moreover, contrary to Cameroon, where there is only one competitive entrance examination, in China, there are two competitive examinations. The first is a national examination for teaching qualification certificate in which contents include writing and interviews part. The second is an examination organised by the local government or school to recruit candidates even though they already got a teaching certificate. Similar to the national examination for teaching qualification certificate, the examination organised by the local government or school includes the writing part and the interviews. A practical demonstration of teaching skill sometimes replaces the interviews. The teaching qualification exam in China is different from Cameroon, where once passing 
the competitive examination and completing the training, candidates are directly integrated into public service. In China, unfortunately, candidates have again to apply for at the local government or school in order to be recruited.

\section{Teacher's Shortage and Causes}

Primary data collected from the respondents confirmed the existing literature on the issue of teacher shortages. In Cameroon, they reported an acute need of teachers, especially in some regions and undeveloped areas such as the Far-North region. While there is a surplus of teachers in the megacity's schools, the less developed and remote area's schools are in an acute need. Teachers reported that besides the subject they had been recruited to teach, they sometimes find themselves teaching other subjects. For instance, one teacher said he was recruited to teach African languages and culture, but he was also assigned to teach French and English due to the shortage of teachers in these subjects in that school.

As in Cameroon, there are also disparities between schools in urban and rural areas in China. However, the gap is less important between schools in urban and remote areas, but it is significant between western regions and eastern part. There is no big gap between small outlying areas. In Jinhua city, for example, there is quite no difference between schools in the cities and peripheral zones. The local government has made that there is no gap between these areas. It is, in fact, the main difference between China and Cameroon. In China, central government and local governments, as far as each is concerned, tremendous efforts are made to reduce the gap in rural areas. Policies and strategies in this regard are various. They include monetary incentives, free housing or housing allowances, travel expenses, a secure promotion and other facilities on the school's campus.

In Cameroon by contrast, there is no such motivating policies and strategies for rural teachers. Many teachers desert disadvantaged areas shortly after their deployment. In addition to no motivating intervention, there is no training opportunities and carrier development. The environment and life conditions may be very different from where they come from, and with no family members around, the adaptation becomes difficult. As result, they are pushed to bribe in order to move in a more conducive area. There is no community rooted practice of teacher recruitment, yet studies show that the recruitment model of the same community-rooted human resource is much more effective in the workforce than other community-rooted individuals. Locally recruited teachers easily adapt to the environment and school culture (Yang, 2015). It is also for this reason that a decentralised system of teacher recruitment and selection is encouraged. Compared to the Chinese system, where teacher's lack is not directly related to the management system; in Cameroon, it is mostly due to the management system. The various reasons mentioned by the respondents have been summarised as follows:

They observed a decrease in the recruitment rate. Many respondents complain and do not understand why the government is reducing every year the number of candidates recruited into HTTC while the same government creates new schools and promotes some lower secondary schools to a complete school cycle. Moreover, there is an inappropriate distribution of teachers across the country. There is a surplus of teachers in big cities' schools, whereas schools in remote areas are in severe lack. Many school principals reported that sometimes teachers sent by the central government come and stay for a short time then disappear. This case is widespread in rural areas.

Another reason mentioned is that many teachers, especially languages' teachers, leave teaching and go abroad to improve their language skill. Once getting a certain level of education, most of them do not longer come back to teach. They choose to pursue further studies in higher education and seek to be employed in the higher education sector. This situation causes an enormous teachers' shortage in those subjects. Furthermore, there is an instability in teaching position. Every year, many teachers are 
promoted to serve as school administrators or called to work in the ministerial departments, and their posts remain vacant for a long time without replacement.

The teacher recruitment system in Cameroon does not meet the challenge that is the need of each school and locality. In addition, this system is marred by poor management practices, associated with the low consideration given to the teaching profession in Cameroonian society, both financially and respectfully. In this regard, once more, China's experience with the consideration towards teacher in the Chinese society and people's mind is a lesson. Teacher and teaching profession are highly valued and respected in Chinese society NCEE (National Center on Education and the Economy), 2020). The loyalty to teaching profession can depend on the consideration given to teachers.

\section{RECOMMENDATIONS AND CONCLUSION}

Based on the findings of the study, this part recommends some good practices for a successful and more balanced system of teacher recruitment and retention. Recommendations mostly go to Cameroon, as it is the one in the position of learning from China.

Firstly, data collected from Cameroon shows that many of the problems originate from the governance and management practices which lead to a teacher's shortage. The centralised governance system gives rise to poor information regarding the needs of schools in terms of teachers. It also leads to a lack of teachers' follow-up. As in China, regional or local governments in Cameroon should be involved in educational administration, especially in recruiting, selecting and retaining practices. This is because they know better their realities and accordingly, the needs. Many studies have proved that the more schools or local governments are involved in teacher recruitment and retention, the more needs are met. Hence, teacher recruitment policy should be reviewed in order to be decentralised to those levels.

Secondly, referring to the lack of information concerning the needs of schools, it is reported that teachers are inappropriately distributed across the country. This inappropriate distribution is, on the one hand, due to the lack of information regarding the needs of schools, and on the other, to the bribery between teachers and agents of distribution. Teachers' distribution and transfer across different regions or schools should be a matter of in-depth analysis in order to respond to the needs expressed by each school. Moreover, a permanent census commission should be created in order to identify the needs of each school. Concerning the measures to be taken to avoid bribery in teacher recruitment and distribution, educational stakeholders should be sensitised, and a national anti-corruption commission, exclusively with regard to the matter should be set up for denouncing and punishing any case of corruption.

Lastly, in Cameroon, respondents have witnessed that there is no motivation for teacher recruitment and retention in undeveloped regions and rural schools. Teachers from rural and urban areas are equally treated despite the bad conditions in those areas. As in China, the Cameroonian government should establish special policies for teacher recruitment and retention in undeveloped areas in order to reduce the gap in teacher' shortage between developed and undeveloped regions. This policy could include monetary incentives, promotion for those who accept to teach in rural areas for a couple of years, and establishing networks and platforms for exchange between schools in rural and urban areas. It should be accompanied by the provision of facilities such as educational materials and improving basic living conditions in order to overcome the precariousness.

Although this research is based on a comparative study between Cameroon and China, its findings and implications can be of use to any country facing the problem of teacher shortage, especially in rural areas. So taken, the study has a general implication. In addition, the findings of this study can be well 
adopted in Cameroon because, of course, it may need some funding to implement some reforms, but it is more about strategies and measures to be taken in accordance with the context.

\section{LIMITATION}

One major limitation affects this study. The research was based in two different systems in which the sample in each country may not be representative of entire system, especially in China where the system is very diversified. Thus, although the use of purposive sampling technique, the results of this study may not be generalised. However, despite this limitation, the study has thrown light on teacher recruitment and retention in both countries; this is thanks to the analysis of official documents of national coverage regarding teachers' management.

\section{FUNDING}

This work was supported by the Open Research Fund of college of Teacher Education,

Zhejiang Normal University (Number JYKF20037).

\section{REFERENCES}

Bahtilla, M. (2017). The impact of working conditions on teachers attrition in secondary schools in the south west region of Cameroon. International Journal of Education and Research, 5(6), 59-78.

Burchill, F., \& Casey, A. (1996). Recruitment and selection. London. Retrieved from https://link.springer.com/chapter/10.1007/978-1-349-24806-3_8

Burns, D., \& Darling-hammond, L. (2014). Teaching around the world: What can TALIS tell us? Stanford. Retrieved from https://edpolicy.stanford.edu/sites/default/files/publications/teaching-aroundworld-what-can-talis-tell-us_3.pdf

$\mathrm{CAB} / \mathrm{PM}$. Circulaire $\mathrm{N}^{\circ} 004 / \mathrm{CAB} / \mathrm{PM}$ du 10 février 2000 Relative à l'admission dans les écoles nationales de formation et au recrutement dans la fonction publique. $<<$ Circular no. 004 / CAB / PM of 10 February 2000 Relative to admission to the National Schools of Train (2000). Cameroon. Retrieved from https://www.minfopra.gov.cm/recueil/REPARATIONS/CIRCULAIRE\%20N\%C2\%B0\%20004$\% 20 \mathrm{CAB}-\mathrm{PM} \% 20 \mathrm{du} . \mathrm{pdf}$

China. Teachers law of the People's Republic of China (1993). Retrieved from http://www.npc.gov.cn/zgrdw/englishnpc/Law/2007-12/12/content_1383815.htm

China. (2014). Statistical Yearbook. (A. and S. Directorate-General of Budget \& R. of C. Executive Yuan, Eds.).

Creswell, J. (2012). Educational research: Planning, conducting and evaluating quantitative and qualitative research. (P. A. Smith, C. Robb, M. Buchholtz, K. Mason, \& J. Sabella, Eds.) (4th ed.). Boston: PEARSON.

Cochrane, S. G., \& Rogers, J. (2019). China 's Provincial Economies: Moody’s analytics.

Djontu Mouafo, H. (2013). La notion de zones d'éducation prioritaires (ZEP) au Cameroun : entre impensé, bricolage et informalité (The notion education priority zones ZEPs in Cameroon:unthought ,DIY, informality). Retrieved March 13, 2019, from http://www.irenees.net/bdf_fiche-analyse1004_fr.html

Eta, E., \& Vuban, J. A. (2018). Educational policy borrowing in the Cameroonian higher education system : a debatable paradigm from stakeholders 'perspectives. Forum for International Research in Education, 4, 77-94. 
Fouka, G., \& Mantzorou, M. (2011). What are the major ethical issues in conducting research? is there a conflict between the research ethics and the nature of nursing? Health Science Journal, 5(1), 3-14.

Gonondo, J., \& Guiake, M. (2017). Comparative study of college admission system based on baccalauréat in Cameroon and gaokao in China. Journal of Education and Practice, 8(29), 30-40.

Haifeng, F., \& Dennis, Y. (2015). Space, scale, and regional inequality in provincial China : A spatial fi ltering approach. Applied Geography, 1-11. https://doi.org/10.1016/j.apgeog.2014.12.022

Hillman, B., \& Unger, J. (2013). Urbanisation in between: Rural traces in a rapidly growing and industrialising county city. Retrieved from https://crawford.anu.edu.au/files/uploads/crawford01_cap_anu_edu_au/2013-09/cp2013-

3_special_feature.pdf

Huang, E., Benson, J., \& Zhu, Y. (2016). Teacher management in China: the transformation of educational systems. https://doi.org/10.4324/9781315693040

Knoema. (2015). Educational fact sheet-Cameroon, 2015. Retrieved from http://haliaccess.org/wpcontent/uploads/2018/05/Cameroon-Education-Facts-Sheet.pdf

Li, Y., \& Wei, Y. H. D. (2010). The spatial-temporal hierarchy of regional inequality of China q. Applied Geography, 30(3), 303-316. https://doi.org/10.1016/j.apgeog.2009.11.001

Liu, Y. (2011). Short-term volunteer teaching in contemporary rural China: A case study on college students' volunteer teaching program of a university in Henan province. Stockholms Universitet.

Lunenburg, F. C., \& Ornstein, A. C. (2012). Educational administration concepts and practices. (Mark Kerr, Ed.) (sixth, ed). USA: Linder Schreiber-Ganster.

MINESUP. (2014). Arreté nº 14 / 029 /MINESUP du 2, 6 Juin 2014 Portant ouverture du concours d'entrée en 1ère année du 2 nd cycle de l'Ecole normale supérieure de l'Université de Yaoundé 1 au titre de l'année académique 2014/2015. Retrieved November 4, 2017, from http://docs.campusjeunes.net/ens_yde22014f.pdf

MINESUP. Arreté N ${ }^{\circ}$ 16/0652/ MINESUP/DU 25 Juil 2016 portant ouverture du concours d'entrée en 1ere année du 2nd cycle de l'Ecole Normal Superieure de Yaounde I au titre de l'année academique 2016-2017.

Cameroon: http://ens.cm/files/communique_ouverture_concours/Arrete_Ouvertue_C2_2016_2017.PDF. Retrieved from http://ens.cm/files/communique_ouverture_concours/Arrete_Ouvertue_C2_2016_2017.PDF

MINESUP. (2017). Arrete $n^{\circ}$ 17/00554 /A/MINESUP/du 06 Sept 2017Portant ouverture du concours d'entrée en 1ère année du 2nd Cycle de l'Ecole Normale Supérieure de l'Université de Yaounde I (ENS Yaounde), au titre de l'année académique 2017-2018. Retrieved November 4, 2017, from https://kamerpower.com/fr/concours-ens-yaounde-2015-2016-1ere-annee-du-2nd-cycle-ens-ecolenormale-superieure-de-luniversite-de-yaounde-1/

MoE. (2016). Number of schools, educational personnel and full-time teachers by type and level. $\begin{array}{llll}\text { Retrieved } & \text { February } & 25, & \text { 2018, }\end{array}$ http://en.moe.gov.cn/documents/statistics/2013/national/201412/t20141215_181591.html

Moraa, S. S., Chepkoech, K. L., \& Simiyu, M. L. (2017). Challenges in the decentralisation of recruitment and selection of teachers in Kenyan secondary schools : A case of Gucha District. Journal of Education and Practice, 8(15), 36-43.

Msuya, V. (2017). Tanzania language of instruction policy: Challenges, problems and prospects. 
Thesis, Zhejiang Normal University.

NCEE (National Center on Education and the Economy). (2020). Shanghai-China: Teacher and principal quality. Retrieved 29 December 2020, from https://ncee.org/what-we-do/center-oninternational-education-benchmarking/top-performing-countries/shanghai-china/shanghai-chinateacher-and-principal-quality/

OECD. (2005). Organisation for economic cooperation and development; teachers matter: attracting developing and retaining effective teachers. Paris, from http://www.oecd.org/education/school/34990905.pdf

OECD. (2016). Education in China: A snapshot. Paris. Retrieved from http://www.oecd.org/education/school/34990905.pdf

Rosalind, E., \& Holland, J. (2013). What is qualitative interviewing? (G. Crow, Ed.) (Bloomsbury, Vol. 7). London: (C) Rosalind Edwards and Janet Holland. https://doi.org/10.5040/9781472545244

See, H., Morris, R., Gorard, S., Kokotsaki, D., \& Abdi, S. (2020). Recruitment and retention: A critical review of international evidence of most promising interventions. Education Sciences, 10(262).

Wanda, C. (2012). Human resource management. (R. Rothwell, William; Prescott, Ed.).

World Bank. (2010). Teacher policies around the world: Objectives, rationale, methodological approach, and products. https://doi.org/:http://dx.doi.org/10.1787/9789264018044-en

World Bank. (2016). Project information document / integrated safeguards data sheet (PID/ ISDS ). Washington, D.C. 20433. https://doi.org/10.1016/j.ridd.2013.01.031

World Bank. (2017). Combined project information documents / integrated Safeguards Datasheet(PID/ISDS).http://documents1.worldbank.org/curated/en/839091517638153085/pdf/Camero on-Education-Reform-Support-Project.pdf

World Bank. (2018). World development report 2018: Learning to realise education's promise. Washington. https://doi.org/10.1596/978-1-4648-1096-1

WorldBank. (2012). Cameroon:governance and management in the education sector. Retrieved from http://documents1.worldbank.org/curated/en/874481468223463602/pdf/NonAsciiFileName0.pdf

Yang, P. (2015). Recruitment and rentention of reachers in rural areas of Guizhou, China. PhD Thesis, University of York. Retrieved from http://etheses.whiterose.ac.uk/15626/

Yearbook. (2016). Number of schools, educational personnel and full-time teachers by type and level. (editorial board and editorial Staff, Ed.). China statistics press. Retrieved from http://www.stats.gov.cn/tjsj/ndsj/2016/indexeh.htm

Yearbook, C. statistical. (2017). Population: Illiterate population to total aged 15 and over. Beijing: China Statistics Press. Retrieved from http://www.stats.gov.cn/tjsj/ndsj/2017/indexeh.htm

Yiu, L., \& Adams, J. (2013). Reforming rural education in China: Understanding teacher expectations for rural youth. China Quarterly, (216), 993-1017.

Zhang, W., \& Bao, S. (2015). Created unequal: China's regional pay inequality and its relationship with mega-trend urbanization. Applied Geography, 1-13. https://doi.org/10.1016/j.apgeog.2014.12.019 